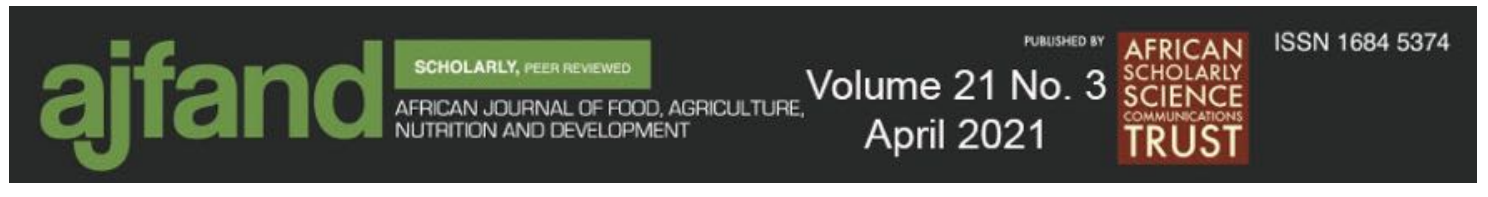

Afr. J. Food Agric. Nutr. Dev. 2021; 21(3): 17696-17710

https://doi.org/10.18697/ajfand.98.20185

\title{
NUTRIENT INTAKES AND NUTRITIONAL STATUS OF CHILDREN OF SAMIN INDIGENOUS PEOPLE IN INDONESIA
}

\section{Riyadi $\mathbf{H}^{1 *}$, Rosidi $\mathbf{A}^{2}$, Margawati $\mathrm{A}^{3}$, Dewi RK ${ }^{4}$ and A Khomsan ${ }^{1}$}

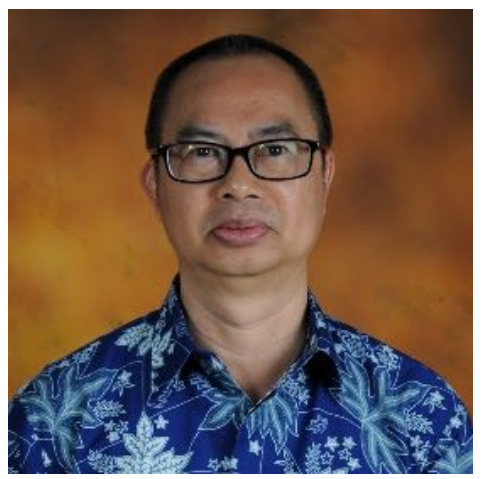

Hadi Riyadi

*Corresponding author email: hadiriyadi@yahoo.com

${ }^{1}$ Department of Community Nutrition, Faculty of Human Ecology, IPB University, Dramaga, Bogor 16680, West Java, Indonesia

${ }^{2}$ Department of Nutrition, Faculty of Nursing and Health Science, Muhammadiyah University of Semarang, Tembalang, Semarang 50273, Central Java, Indonesia

${ }^{3}$ Department of Nutrition, Faculty of Medicine, Diponegoro University, Tembalang, Semarang 50275, Central Java, Indonesia

${ }^{4}$ Department of Nutrition, Faculty of Public Health, Andalas University, Limau Manis, Padang 25613, West Sumatera, Indonesia 




\begin{abstract}
Undernutrition is still a problem in the world. In Indonesia, the problem of undernutrition is high especially underweight, stunting and wasting among children under five years old. Some indigenous people usually have lower economical levels, educational levels and health status compared to the rest of the population and as a result indigenous people are usually prone to malnutrition. Samin is one example of indigenous people in Indonesia. The main objective of this study was to compare nutrient intakes and nutritional status of children under five years in Closed and
\end{abstract} Opened Samin indigenous people in Indonesia. Closed Samin people tend to hold on to their culture firmly and are less receptive to some government programs, while Opened Samin tend to be more receptive to government programs. This was a cross-sectional study design. Participants were selected by snowball sampling technique; 120 households with children under five years were selected. Food consumption of the children was collected through direct interviews using 1x24 hours recall procedure. Nutritional status was assessed by weighing the children's body weights. Children's anthropometric data were analyzed using the WHO Anthro Plus software. T-test and Mann-Whitney were used to analyze the difference between groups. The study showed that nutrient intakes (energy, protein, vitamin A, iron and calcium) of children in Closed Samin were significantly lower than those in Opened Samin $(p<0.05)$. The vitamin $C$ intake of both groups was not significantly different ( $>0.05)$. The mean of energy, vitamin $\mathrm{C}$ and calcium intake in both groups did not meet Indonesian Recommended Dietary Allowances (RDA). Based on the RDA reference, protein and vitamin A adequacy of children in Closed Samin and Opened Samin were sufficient. Iron adequacy was different in Closed Samin classified as inadequate, whereas Opened Samin was normal. The prevalence of underweight in Closed Samin was 49\%, while in Opened Samin it was 21\%. The weight-for-age Z-score (WAZ) of children in both groups showed significant differences $(\mathrm{p}=0.006)$ with mean $\mathrm{z}$-score $-1.8 \pm 1.4$ for Closed Samin and $-1.1 \pm 1.4$ for Opened Samin. In conclusion, the mean of nutrient intakes and nutritional status of children in Opened Samin was higher than Closed Samin. That was due to the household economic levels and maternal nutritional knowledge, which was also higher in Opened Samin. The local government must find the best approach in resolving problems related to child nutrition of Closed Samin indigenous people and be more active to encourage participation in government programs.

Key words: Children, Indigenous People, Nutrient Adequacy, Socio-Economic, Underweight 


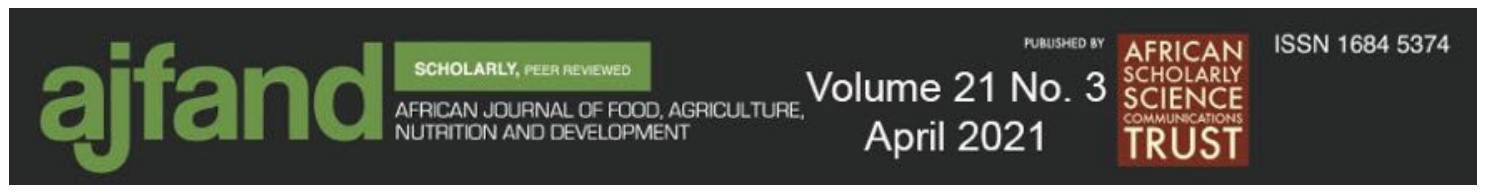

\section{INTRODUCTION}

Undernutrition is still a problem in the world, including in Indonesia. The National Health Research conducted in 2018 showed that nationally, the prevalence of underweight, stunting and wasting of children under five years in Indonesia were $17.7 \%, 30.8 \%$, and $10.2 \%$, respectively [1]. Nutritional status is determined by many factors, either direct or indirect [2]. A child's dietary intake and health status both directly determine nutritional status. Both factors (dietary intake and health status) are determined by many underlying factors, such as food security, caring practice and resources for health. Underlying factors are determined by basic factors, such as political and economic structure, socio-cultural environment, and potential resources. A study by Hidayat and Prasetyo [3] found that factors of family income, maternal education, history of infectious disease, and maternal knowledge simultaneously affected malnutrition in children.

Indigenous peoples have a cultural heritage for centuries, which is still applied in daily life. The culture of each indigenous people is different and unique. Indigenous people usually have lower economic levels, lower educational levels and lower health status compared to the rest of the population and as a result, they are usually prone to malnutrition [4]. Escobar et al. [5] found that among indigenous people in Brazil, higher risk of diarrhoea was observed among younger children and those who had less maternal schooling and lower household socioeconomic status.

Health status of indigenous people is always poorer than that of non-indigenous people. Indigenous people suffered lower life expectancy, high infant and child mortality, high maternal morbidity and mortality, heavy infectious disease loads, undernutrition, stunted growth, increasing levels of cardiovascular and other chronic diseases, substance abuse and depression [6]. In Indonesia, a study on children's indigenous people was conducted in several communities: Baduy and Ciptagelar. Khomsan et al. [7] conducted a study in the Baduy tribe and reported that about $26 \%$ of children under five years were underweight, $61 \%$ were stunted, and $17 \%$ of them were wasted. Furthermore, at Kasepuhan Ciptagelar it was found that $13 \%$ of children were underweight, $31 \%$ were stunted and $13 \%$ were wasted [8].

Samin people (Sedulur Sikep) are the indigenous people who live in the North region of Java Island, more precisely in the Central Java province and some parts of East Java province. Samin indigenous people are different from any other indigenous people. They were not centralized in one region but they were spread in some regions all along Kendeng Mountain Range in the Northern part of Java Island. Some of the Samin indigenous people still uphold the culture, namely, Closed Samin. They tend to shy away from some government programs. The Closed Samin live in Districts of Pati and Kudus. The others are more receptive to government programs, namely Opened Samin. They live in District of Blora [9]. This research aimed to compare nutrient intakes and nutritional status of children under five years in Closed and Opened Samin indigenous people in Indonesia. 


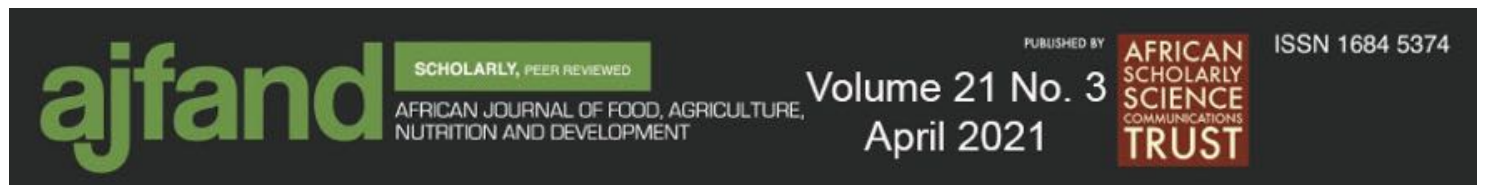

\section{MATERIALS AND METHODS}

\section{Study Design and Samples}

The study design in this research was cross-sectional. The study population was households with children under five years, of Samin indigenous people from three districts in Central Java Province, namely Kudus, Pati, and Blora. The research studied two Samin communities in the Central Java Province area, namely Closed Samin and Opened Samin. Samin people in Kudus and Pati represent the Closed Samin who tend to hold their culture firmly and close out the government. While Samin people in Blora represent the Opened Samin who tend to be more receptive to government programs.

The snowball sampling technique was used in this study because there was unavailability of the official record of Samin people, making it difficult for the sampling to be made. A total of 120 samples were analyzed consisting of 68 Closed Samin households and 52 Opened Samin households. The respondents in this research were the mother of children under five years (1-60 months).

\section{Data collection}

Data on socio-economic characteristics and food consumption of children were collected through interviews using a set of questionnaires. The socio-economic questionnaire was pre-tested in 10 households in Demak District before being administered to the respondent to make sure that the instrument is understandable and can be filled out by enumerators. The food consumption data were collected using a standard questionnaire [10]. Children's weights were measured using a digital scale to the nearest $0.1 \mathrm{~kg}$. Socio-economic characteristics consisted of household economic level and maternal nutritional knowledge.

The Central Bureau of Statistics in Indonesia classifies a household as poor or non-poor based on economic status. The poverty index based on foods and non-foods expenditure was set US\$24/capita/month [11]. The maternal nutritional knowledge among Samin people was classified into 2 groups according to score of correct answer (below and above the mean score).

Food consumption data of children were collected using a 24-hour recall questionnaire by interviewing the mothers. The amount of food consumed was measured using Indonesian standard portion based on Food Picture Book of Indonesia [12]. The book contains pictures of food commonly consumed by Indonesian people in standard portion and household measurements (such as tablespoon, bowl, medium slice). Nutrient intakes were calculated using the Nutrisurvey software [13] based on Indonesian food composition tables [14]. The nutrient intakes were then compared to Indonesian RDA to determine the adequacy level [15]. The nutrients presented are energy, protein, vitamin A, vitamin C, iron, and calcium which were usually deficient among children in Indonesia [16].

Nutritional status was assessed by weighing the children's body weights. Then, Zscores were obtained from a calculation using WHO Anthro Plus software [17]. Children's nutritional status was determined by weight for age z-score. Recumbent 




height (length) measurement was prohibited by local leaders because it was identical to the burial process in Samin communities. Therefore, height-for-age and weight-forheight $\mathrm{z}$-scores were unavailable. Weight- for- age Z-score category divided into four groups, that is severe underweight $(Z$-score $<-3 S D)$, moderate underweight $(-3 \mathrm{SD}<\mathrm{Z}$ score $<-2 \mathrm{SD}$ ), normal (-2SD $<\mathrm{Z}$-score $<2 \mathrm{SD}$ ), and overweight (Z-score $>2 \mathrm{SD}$ ).

\section{Statistical analyses}

Data were analyzed based on questionnaires and anthropometric measurement results using the IBM program Statistical Package for Social Sciences (SPSS) version 23 2016. Anthropometric data were analyzed using the Anthro Plus software of WHO. Statistical data analysis were performed using SPSS version 21.0. Descriptive statistics such as mean, standard deviation (SD), frequencies, and proportion were calculated. To analyze the difference between groups, t-test and Mann-Whitney were performed. Significance was reported when $\mathrm{p}$-value $<0.05$.

\section{Ethical approval}

Ethical approval was obtained from the Bioethics Committee for Medical/Health Research of The Faculty of Medicine, Sultan Agung Islamic University, Semarang, No. 183/VII/2017. The purpose of the study, the procedures, issues concerning confidentiality, and their freedom to participate or withdraw from the study were explained to all participants during recruitment.

\section{RESULTS AND DISCUSSION}

\section{Socio-economics status}

Table 1 shows that most families in Closed Samin are classified as poor (60\%), while in the Opened Samin 73\% are non-poor families. In general, the household income was allocated for various purposes such as food consumption, daily needs, child's school needs, social activities and other needs. The household expenditure in this study was divided into two groups, namely food and non-food expenditures. Total food expenditure in Closed Samin and Opened Samin (59.6\% and 58.8\%) was higher than non-food expenditure ( $40.4 \%$ and $41.2 \%$, respectively).

The staple food expenditure still became the biggest expenditure on food expenditure, followed by the animal-based protein expenditure and snacks expenditure in both groups of Samin People. Expenditure on cigarettes had the highest percentage on nonfood expenditure which was followed by fuel and sanitation expenditures, either in Closed Samin or Opened Samin. Overall, the largest household expenditure of the Samin People was for staple food (16.5\%). Our study showed cigarettes, precisely, became the second largest (14.6\%) contributor to the expenditure of Samin People, followed by animal-based protein expenditure (11.7\%) and fuel expenditure (10.5\%).

The economic level of Closed Samin and Opened Samin was significantly different $(\mathrm{p}<0.001)$. Low-income households faced limited access to and purchasing of food. Achilana et al. [18] stated that households with a high income had significantly increased food security. Child malnutrition was influenced by many factors and one of 


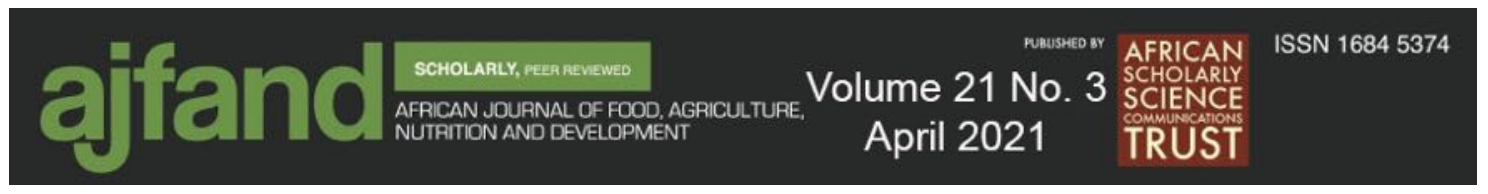

them was low family income. A study in Ethiopia [19] showed that children in poor households were prone to malnutrition.

Nutritional knowledge is an individual's understanding of nutrition, including the intellectual ability to remember and recall food- and nutrition-related terminology, specific pieces of information and facts. Nutritional knowledge is really important for a mother since it will influence their perception, decision, even practices regarding their children's nutritional status [4].

The nutritional knowledge questionnaires in this study included questions about: staple food as source of carbohydrate, the function of fruits and vegetables, the importance of breakfast, food safety aspects, sanitation and disease, the importance of iodized salt consumption, and the importance of a child's growth monitoring. The maternal nutritional knowledge among Samin people was classified as moderate with an average score of $66.5 \pm 21.8$. A significant difference $(\mathrm{p}<0.001)$ was seen between the maternal nutritional knowledge in Opened Samin $(75.4 \pm 19.3)$ that was higher than the one in Closed Samin (59.7 \pm 21.3 ). Most of the mothers (93.3\%) in the Samin community had understood about the food sources of energy. However, $43.3 \%$ of mothers understood goiter and that the consumption of iodized salt was able to prevent the disease.

Maternal nutritional knowledge was affected by the formal education level. A study conducted by De Vriendt et al. [20] on 803 women found that the important factors which influenced nutritional knowledge were women's education level, age, and type of occupation. Mothers who are well educated can easily practice new information obtained through mass media and health education [21]. The level of education showed a positive relationship with high knowledge, including nutritional knowledge. Mothers with less than senior high school education tended to have stunted children (74.2\%) compared to mothers with higher education [22].

The low education level of Samin people is due to their culture. Not going to school is one of the doctrines adhered to in the Samin community because they believe that education should be given by their parents. The education level of mothers in Closed Samin is lower than Opened Samin because most people in Closed Samin (95.6\%) did not attend school. This is different from the level of education in the Opened Samin, where more than $95 \%$ have attended school and $28.8 \%$ of mothers in Opened Samin have a high level of education. Since 2009, children from Closed Samin began to study at kendeng house (like village meeting hall) every Monday. In there, they were taught to read, write, sing, and play gamelan (Javanese music tools) [23].

The lack of parental education on health and nutrition can be one of the causes of the high prevalence of health problems in the Samin community, especially children under five years of age. The results of a study conducted by Kabahenda et al. [24] summarized that nutrition education significantly improved the feeding practices and children's nutritional status. 


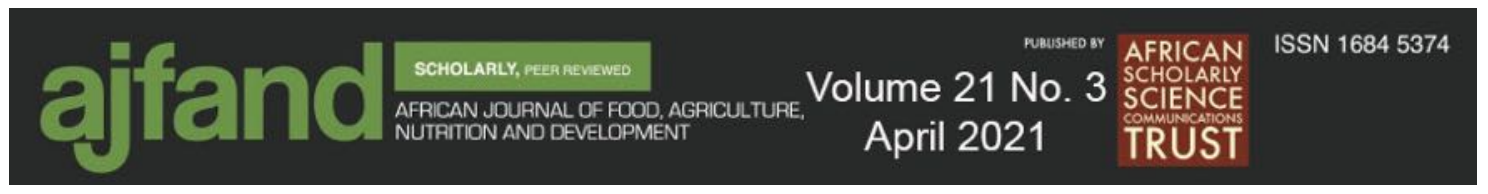

\section{Nutrient intakes of children}

The children's food intakes are presented in Table 2. The energy and nutrient intakes of the children in Opened Samin are higher than the ones in Closed Samin. The t-test analysis also showed significant differences $(p<0.05)$ between the children's nutrient intakes in Opened Samin and Closed Samin, except for vitamin C intake.

Similar results were also seen on the nutrient adequacy levels. The mean adequacy level (\%RDA) of vitamin A and iron of children was significantly lower in Closed Samin than those in Opened Samin $(p<0.05)$. Intake of energy, vitamin $C$, and calcium did not meet with the Indonesian Recommended Dietary Adequate (RDA) in both groups, except for protein and vitamin A. Iron adequacy was different between the two groups, in Closed Samin classified as inadequate, whereas Opened Samin was normal.

Food sources of iron were commonly found in animal foods and dark green leafy vegetables. Leão et al. [25] revealed that the number of children aged 6-24 months who consumed meat was only $38.2 \%$. Inadequate consumption of meat was due to high price. A study in India from low-income households showed the percentage of iron adequacy in children below 24 months was $18.5 \%$ compared to average requirements [26]. In another study in the Philippines, $75 \%$ of children had insufficient iron intake [27].

The dietary pattern of Samin people depends more on the produce from the earth. Samin people never buy rice because almost all of them are farmers so they get rice supply from their own harvest. They also get vegetables, fruits, and animal source foods from their own garden. They buy other foods from the market, but the sellers are not Samin people because they are not allowed to trade. Rice was consumed by $100 \%$ of Samin people. Protein intake mainly comes from the consumption of tofu (food made from condensed soy milk) and tempeh (fermented food made from soybean) which is consumed almost every day. Besides tofu and tempeh, eggs were a source of animal protein that was often consumed.

Besides breastfeeding, new-born babies were fed solid foods consisting of mashed rice, banana, or vegetable soup. According to parents and grandmothers, if the baby is constantly crying, it means that the baby is hungry. During in-depth interview at Closed Samin, all mothers stated that food was given to babies before 6 months because breastfeeding is considered not enough to support growth. Mothers in Opened Samin, on the other hand, have understood that solid food can only be given to babies after 6 months old and before 6 months they are only given breast milk.

A study in the Philippines showed that diets of children were composed of a large amount of rice and other low nutrient-dense foods (such as cookies and sugar), while vegetables, fruits, meats, and eggs made little contribution to daily energy and nutrients [27]. The high proportion of children with an inadequate intake of vitamins and minerals might be caused by the children's dislike of vegetables and fruits or the lack of access to vegetables and fruits. The introduction of complementary feeding and dietary practices of the family to the children can be reflected in the habit of the child. A study in rural China found that parental knowledge training through knowledge 


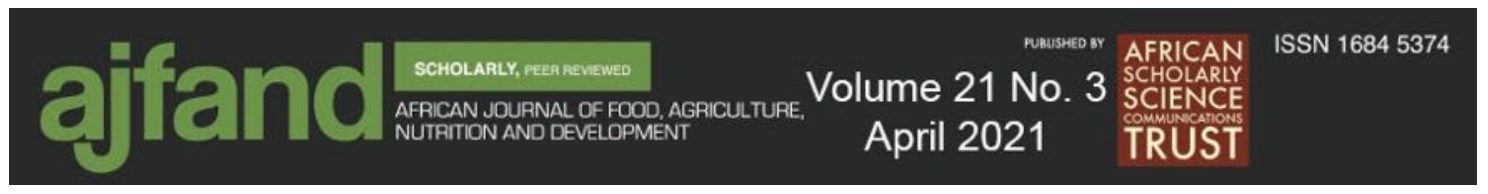

improvement and dietary change has increased children's hemoglobin level by $2.8 \mathrm{~g} / \mathrm{dl}$, on average [28].

\section{Nutritional status of children}

Table 3 shows that the average age of children in this study was $26.6 \pm 16.7$ months in Closed Samin and 27.6 \pm 16.9 months in Opened Samin. Body weight of children in Opened Samin $(10.6 \pm 3.4 \mathrm{~kg})$ was higher than in Closed Samin $(9.6 \pm 2.7 \mathrm{~kg})$, but the difference was not statistically significant $(\mathrm{p}=0.063)$.

The weight-for-age Z-score (WAZ) of children in both groups showed significant differences $(\mathrm{p}=0.006)$ with mean $\mathrm{z}$-score $-1.8 \pm 1.4$ for Closed Samin and $-1.1 \pm 1.4$ for Opened Samin. Almost half (48.5\%) of the children in Closed Samin were underweight while in Opened Samin about one in five $(21.1 \%)$ children were underweight. The underweight prevalence of Samin children found in this study was higher than that of Indonesian children based on a national survey (16.3\%) [29]. A study by Abdulahi et al. [30] stated that risk factors of undernutrition in children were child age, child sex, complementary food, poor dietary diversity, diarrheal diseases, maternal education, maternal height, residential area, and socio-economic status [30].

The nutritional status of Samin's children was also influenced by their participation in Posyandu (integrated service post) activities. Only one-third of mothers in Closed Samin brought their children to Posyandu every month to be weighed and get a vaccination. They believed that their children were healthy; so, the children did not need to be weighed. This condition was different from the people in Opened Samin who had been aware of the importance of Posyand $u$ for their children's health. The mothers who did not take their children to the Posyandu were certainly not well informed about health programs. The mothers in Opened Samin with a high level of attendance at Posyandu were more exposed to health information because they received health education/counseling at Posyandu. Therefore, their children's nutritional status was better than that of children in Closed Samin.

\section{CONCLUSION}

In conclusion, the mean of nutrient intakes and nutritional status of children in Opened Samin was higher than in Closed Samin. This was due to the household economic level and maternal nutritional knowledge which is also higher in Opened Samin. Local government, especially District Health Office, District Education, and Cultural Offices must find the best approach toresolve problems related to the public health of Samin people. Further, they should encourage Closed Samin people to participate in government programs related to education and nutritional knowledge to enhance the nutritional status of their children.

\section{AUTHORS' CONTRIBUTIONS}

The authors' responsibilities were as follows: HR \& AR designed the study. RKD supervised, collected and ensured the quality of the data. RKD, AM, \& AK analyzed and interpreted the data. All authors critically reviewed the manuscript. After all the 


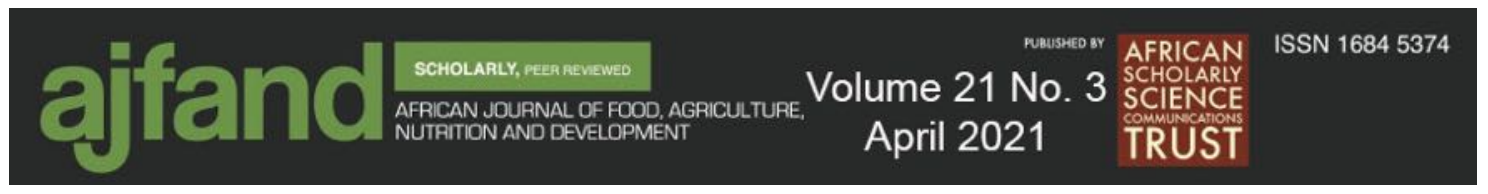

authors gave final approval of the paper to be published, HR, the corresponding author was responsible to submit the manuscript for publication.

\section{ACKNOWLEDGEMENTS}

The authors are grateful to the Neys-van Hoogstraten Foundation, the Netherlands for funding this study. Appreciation goes to local government in Kudus, Pati, and Blora for giving research permits, and Samin leaders and the mothers for participating in the study. Special thanks go to the research assistants and enumerators who collected data in the field.

\section{CONFLICT OF INTEREST}

The authors declared no potential conflicts of interest concerning the research, authorship, and/or publication of this article.

\section{FUNDING}

This project was supported by a grant from the Neys-van Hoogstraten Foundation, the Netherlands (IN289). 


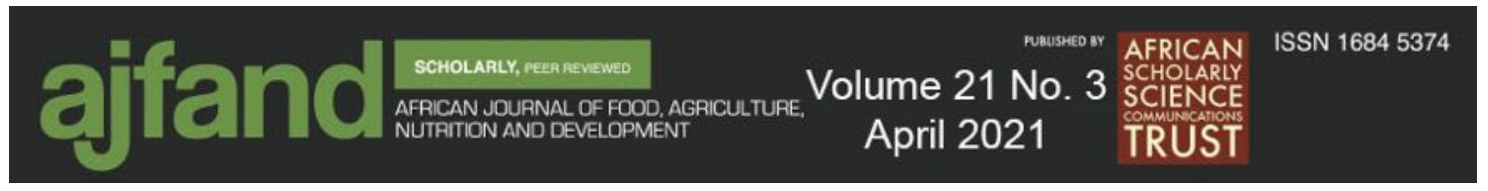

Table 1: Socio-economics status of Samin community

\begin{tabular}{|c|c|c|c|}
\hline Variables & $\begin{array}{l}\text { Closed Samin } \\
\qquad(\mathrm{n}=68)\end{array}$ & $\begin{array}{l}\text { Opened Samin } \\
\qquad(\mathrm{n}=52)\end{array}$ & p-value \\
\hline \multicolumn{4}{|c|}{ Household economic level [(\%) n] } \\
\hline Poor & $(60.3) 41$ & $(26.9) 14$ & \\
\hline Non-poor & (39.7) 27 & $(73.1) 38$ & \\
\hline $\begin{array}{l}\text { Mean expenditure } \pm \text { SD } \\
\text { (US\$/cap/month) }\end{array}$ & $24 \pm 8$ & $33 \pm 14$ & $<0.01$ \\
\hline \multicolumn{4}{|c|}{ Maternal nutritional knowledge $[(\%)$ n] } \\
\hline Below mean score & $(50.0) 34$ & $(46.2) 24$ & \\
\hline Above mean score & $(50.0) 34$ & $(53.8) 28$ & \\
\hline Mean score \pm SD & $59.7 \pm 21.3$ & $75.4 \pm 19.3$ & $<0.01$ \\
\hline
\end{tabular}




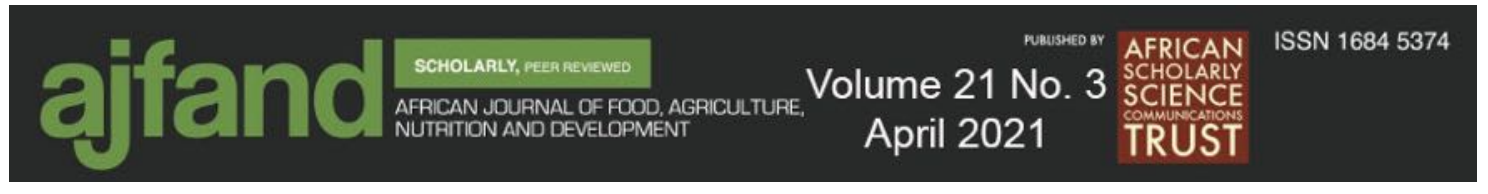

Table 2: Nutrient intakes of children in Samin community

\begin{tabular}{|c|c|c|c|}
\hline Variables & $\begin{array}{l}\text { Closed } \\
\text { Samin } \\
(n=68)\end{array}$ & $\begin{array}{l}\text { Opened Samin } \\
\qquad(\mathrm{n}=52)\end{array}$ & p-value \\
\hline \multicolumn{4}{|c|}{ Nutrient Intakes (mean \pm sd) } \\
\hline Energy (kcal) & $625 \pm 283$ & $793 \pm 393$ & $0.016^{*}$ \\
\hline Protein $(g)$ & $17.7 \pm 10.1$ & $23.6 \pm 13.9$ & $0.023 *$ \\
\hline Vitamin A (RE) & $360 \pm 290$ & $550 \pm 348$ & $0.001 *$ \\
\hline Vitamin C (mg) & $16.4 \pm 25.0$ & $21.4 \pm 23.2$ & 0.059 \\
\hline Iron (mg) & $4.2 \pm 3.1$ & $5.9 \pm 4.5$ & $0.045^{*}$ \\
\hline Calcium (mg) & $201 \pm 139$ & $310 \pm 274$ & $0.029 *$ \\
\hline \multicolumn{4}{|l|}{$\% \operatorname{RDA}(\operatorname{mean} \pm$ sd) } \\
\hline Energy & $76.8 \pm 30.1$ & $85.7 \pm 32.2$ & 0.115 \\
\hline Protein & $94.1 \pm 48.5$ & $109.5 \pm 55.2$ & 0.208 \\
\hline Vitamin A & $88.2 \pm 68.0$ & $134.1 \pm 84.7$ & $0.001 *$ \\
\hline Vitamin C & $39.9 \pm 59.6$ & $51.5 \pm 56.3$ & 0.078 \\
\hline Iron & $60.9 \pm 36.1$ & $80.9 \pm 50.6$ & $0.044^{*}$ \\
\hline Calcium & $39.9 \pm 37.9$ & $54.5 \pm 55.7$ & 0.060 \\
\hline
\end{tabular}

*significant differences $(\mathrm{p}<0.05)$ 


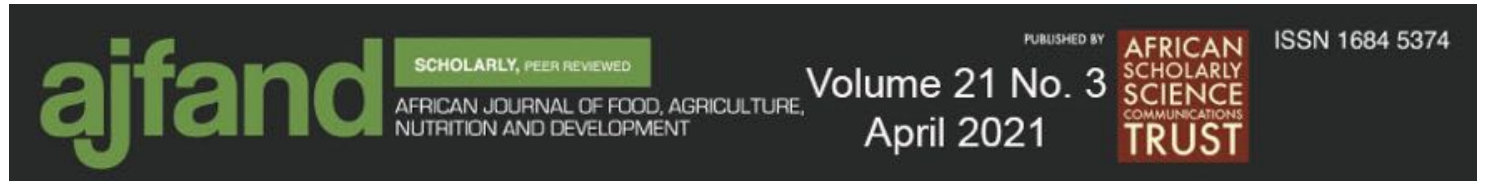

Table 3: Children's characteristics and nutritional status of Samin community

\begin{tabular}{|c|c|c|}
\hline Variables & $\begin{array}{l}\text { Closed } \\
\text { Samin } \\
(n=68)\end{array}$ & $\begin{array}{l}\text { Opened } \\
\text { Samin } \\
(n=52)\end{array}$ \\
\hline Age (months; mean \pm SD) & $26.6 \pm 16.7$ & $27.6 \pm 16.9$ \\
\hline Weight $(\mathrm{kg} ;$ mean $\pm \mathrm{SD})$ & $9.6 \pm 2.7$ & $10.6 \pm 3.4$ \\
\hline p-value of weight & \multicolumn{2}{|c|}{0.063} \\
\hline \multicolumn{3}{|l|}{ WAZ } \\
\hline Severe underweight (Zscore <-3SD); [(\%) n] & $(20.6) 14$ & $(11.5) 6$ \\
\hline Moderate underweight $(-3 \mathrm{SD}<$ Zscore $<-2 \mathrm{SD}) ;[(\%) \mathrm{n}]$ & (27.9) 19 & $(9.6) 5$ \\
\hline Normal $(-2 \mathrm{SD}<$ Zscore $\leq 2 \mathrm{SD}) ;[(\%) \mathrm{n}]$ & $(51.5) 35$ & $(76.9) 40$ \\
\hline Overweight (Zscore $>2 \mathrm{SD}) ;[(\%) \mathrm{n}]$ & $(0.0) 0$ & $(1.9) 1$ \\
\hline Mean Z-score \pm SD & $-1.8 \pm 1.4$ & $-1.1 \pm 1.4$ \\
\hline p-value of WAZ & \multicolumn{2}{|c|}{$0.006^{*}$} \\
\hline
\end{tabular}

*significant differences $(\mathrm{p}<0.05)$ 


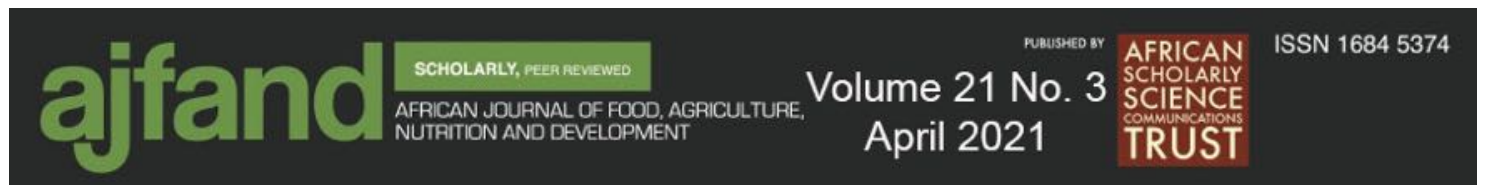

\section{REFERENCES}

1. Ministry of Health of Indonesia. National Health Research Report 2018. The Directorate General of Public Health, Ministry of Health of Indonesia, Jakarta, 2018.

2. UNICEF. Strategy for improved nutrition of children and women in developing countries. UNICEF, New York, 1990.

3. Hidayat AAA and E Prasetyo Research Article Predictors of Malnutrition in Children Aged Less than 5 Years in Surabaya, Indonesia. Pakistan. J. Nutr. 2018; 17(12):641-646.

4. Kuhnlein H, Erasmus B, Spigelski D and B Burlingame Indigenous People'sfood system \& well-being interventions \& policies for healthy communities. FAO, Rome, 2013.

5. Escobar AL, Coimbra Jr CE, Welch JR, Horta BL, Santos RV and AM Cardoso Diarrhea and Health Inequity among Indigenous Children in Brazil: results from the First National Survey of Indigenous People's Health and Nutrition. BMC. Public. Health. 2015; 15:191.

6. Valeggia CR and JJ Snodgrass Health of Indigenous Peoples. Annu. Rev. Anthropol. 2015; 44:117-135.

7. Khomsan A and W Wigna Sosio-Budaya Pangan Suku Baduy (Socio-Cultural Aspects of Food of Baduy Tribe). J. Nutr. and. Food. 2009; 4(2):63-71.

8. Khomsan A, Riyadi H, Marliyati SA and LD Jayanti Sistem Pangan dan Gizi Masyarakat Adat Kasepuhan Ciptagelar di Jawa Barat (Food and Nutrition System of Kasepuhan Ciptagelar Indigenous People in West Java). IPB Press, Bogor. 2014: 57.

9. Rizqi MN and H S Rini Formal Education in Sedulur Sikep Perspective (Case Study on Sedulur Sikep, Klopoduwur Village, Blora Regency). Solidarity. 2015; 4(2): 71-85.

10. Gibson RS Principles of Nutritional Assessment. Oxford University Press, New York. 2005: 42.

11. Central Bureau of Statistics. Jawa Tengah Province in Figures 2017. Central Bureau of Statistics of Central Java, Semarang, 2017.

12. Individual Food Consumption Survey Team. Buku Foto Makanan (Food Picture Book of Indonesia). Ministry of Health Republic of Indonesia, Jakarta, 2014.

13. Briend $\mathbf{A}$ and $\mathbf{J}$ Erhardt Linear Programming Module of NutriSurvey. Available: http://www.nutrisurvey.de/lp/lp.htm Accessed 8 December 2020.

14. Ministry of Health Republic of Indonesia. Food Composition Table 2017. Jakarta: Ministry of Health Republic of Indonesia, 2018. 


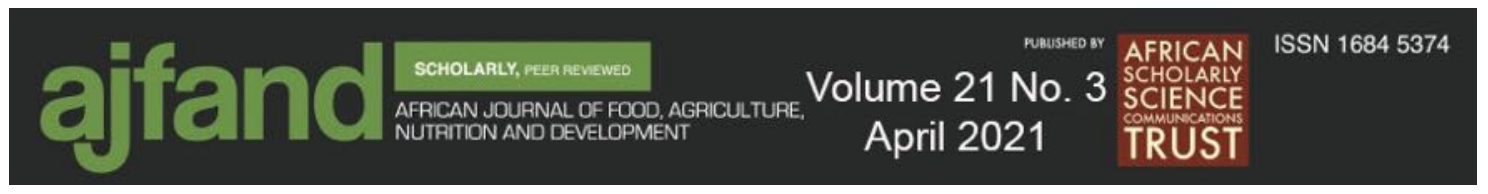

15. Ministry of Health Republic of Indonesia. Regulation of Minister of Health Republic of Indonesia No. 75 of 2013 about Indonesian RDA, Jakarta, 2013.

16. Sandjaja S, Budiman B, Harahap H, Ernawati F, Soekatri M, Widodo Y, Sumedi E, Rustan E, Sofia G, Syarief SN and I Khouw Food Consumption and Nutritional and Biochemical Status of 0.5-12-year-old Indonesian Children: the SEANUTS Study. Br. J. Nutr. 2013; 110: S11-S20.

17. Blössner M, Siyam A, Borghi E, de Onis M, Onyango A, Yang H, Erhardt J, Goumaz S and L Dobler WHO Anthro for Personal Computers Manual Software for Assessing Growth and Development of the World's Children. World Health Organization and Department of Nutrition for Health and Development, Geneva, 2010.

18. Achilana M, O'Connor D and T Mkamwa Low Income Farm Households' Access to Markets and Household Food Security: The Case of Two Economically Distinct Areas in Rural Tanzania. Afr. J. Food. Agric. Nutr. Dev. 2020; 20(3):15876-15897.

19. Woldeamanuel BT and TT Tesfaye Multivariate Analysis of Correlates of Under Five Children Malnutrition in Tigray Region, Ethiopia. Math. Model. Appl. 2019; 4(4):49-63.

20. De Vriendt T, Matthys C, Verbeke W, Pynaert I and S De Henauw Determinants of Nutrition Knowledge in Young and Middle-Aged Belgian Women and The Association with Their Dietary Behaviour. Appetite. 2009; 52:788-792.

21. Dereje H, Haymanot A and T Degefa Predictors of Child Stunting in Fitche Town, North Shewa Zone, Ethiopia. Afr. J. Food. Agric. Nutr. Dev. 2020; 20(3):15992-16012.

22. Wicaksono F and T Harsanti Determinants of Stunted Children in Indonesia : A Multilevel Analysis at the Individual, Household, and Community Levels. Kesmas. Natl. Public. Heal. J. 2020; 15(64):48-53.

23. Nugrahayuningtyas A Peran Gender dalam Perekonomian Rumah Tangga Petani pada Masyarakat Adat (Gender Roles in The Economics of Farming Households in Indigenous Communities). IPB University, 2017.

24. Kabahenda M, Mullis R, Erhardt J, Northrop-Clewes C and S Nickols Nutrition Education to Improve Dietary Intake and Micronutrient Nutriture among Children in Less-resourced Areas: A Randomised Controlled Intervention in Kabarole District, Western Uganda. S. Afr. J. Clin. Nutr. 2011; 24(2):83-88.

25. Leão LL, Antunes BA, Oliveira CA, Brito MFSF and L de Pinho Food Sources of Iron and Vitamin C Consumed among Infants in Primary Healthcare. Cogitare. Enferm. 2018; 23(2):e51908.

26. Bains K, Kaur H, Bajwa N, Kaur G, Kapoor S and A Singh Iron and Zinc Status of 6-Month to 5-Year-Old Children From Low-Income Rural Families of Punjab, India. Food. Nutr. Bull. 2015; 36(3):254-263. 




27. Denney L, Angeles-Agdeppa I, Capanzana M V, Toledo MB, Donohue J and A Carriquiry Nutrient Intakes and Food Sources of Filipino Infants, Toddlers and Young Children are Inadequate: Findings from the National Nutrition Survey 2013. Nutrients. 2018; 10(11):1730.

28. Zhao Q and X Yu Parental Nutrition Knowledge, Iron Deficiency, and Child Anaemia in Rural China Parental Nutrition Knowledge, Iron Deficiency, and Child Anaemia in Rural China. J. Dev. Stud. 2020; 56(3):578-595.

29. Ministry of Health of Indonesia. Hasil Pemantauan Status Gizi Tahun 2017 (The Report of Nutritional Status Monitoring 2017). The Directorate General of Public Health, Ministry of Health of Indonesia, Jakarta, 2018.

30. Abdulahi A, Shab-bidar S and S Rezaei Nutritional Status of Under Five Children in Ethiopia: A Systematic Review and Meta-Analysis. Ethiop. J. Heal. Sci. 2017; 27(1):175-188. 